\title{
Evolution of Blood Clotting Factor Levels in Premature Infants during the First 10 Days of Life: A Study of 96 Cases with Comparison Between Clinical Status and Blood Clotting Factor Levels
}

\author{
Anne Hurlet-Birk Jensen ${ }^{[30]}$, Françors Josso, Pierre Zamet, Miahèle Monset-Couchard, \\ and Alexandre Minkowski \\ With the Teghnical Assistance of Nigole Savagluo \\ Centre de Recherches Biologiques Néonatales, Centre Hospitàlier Universitaire Cochin, and the Department of Hematology, \\ Centre Hospitàlier Universitaire Necker-Enfants Malades, Paris, France
}

\begin{abstract}
Extract
Fibrinogen and factors $V, I I$, and $V I I+X$ assays were performed by micromethod on days $1,2,3$, and 10 of life in 96 premature infants (<37 weeks gestational age). "Sick" premature infants, mainly with respiratory distress syndrome, were compared with premature infants considered to be thriving. In the thriving infants, the mean level of the studied clotting factors appears to be independent of gestational age. Fibrinogen and factor $V$ levels are correlated in thriving as well as in sick infants; both are significantly decreased in the sick infant group. In both groups, factors $I I$ and $V I I+X$ levels were consistently low on the 1st day of life. They progressively increased but did not reach adult levels by the 10 th day of life despite routine vitamin $\mathrm{K}_{1}$ administration. Overall mortality as well as clinical hemorrhagic manifestations were closely related to blood clotting factor levels. Pathologic and biologic data indicate a relation between coagulation abnormalities in premature infants and the occurrence of disseminated intravascular clotting.
\end{abstract}

\section{Speculation}

It can be postulated that low levels of blood clotting factors result from either diminished production (immaturity, toxicity, etc.) or increased utilization or consumption (i.e., disseminated intravascular coagulation (DIC)). Hypercoagulability and disseminated intravascular coagulation have been described in premature infants, especially in those with respiratory distress. By means of microtechnics, it is now possible to study the evolution of blood clotting factor levels in premature infants with and without respiratory distress in an attempt to better understand the relation of blood clotting levels and the presence of DIC.

\section{Introduction}

Previous work [16] has demonstrated that a reliable assay of all clotting factors can be performed on capillary blood by micromethod. This method is particu- larly useful for analysis of the rapid changes in the hemostatic system in neonates.

Most of the hemorrhagic syndromes in newborn infants can be diagnosed simply by using a platelet 
count and a few clotting factor assays, i.e., fibrinogen and factors $V, I I$, and $V I I+X$. In this period of life it is necessary to use specific assays of clotting factors instead of the classic screening tests because of the frequent association of the so called "hypercoagulability" and various clotting defects. This method has been applied to the study of 96 premature infants during the first 10 days of life. The results observed in thriving premature infants were compared with those of sick premature infants, particularly in cases with respiratory distress (RD).

\section{Patients and Methods}

\section{Patients (Table I)}

This study included 96 infants, all of whom received at least two coagulation studies except in a few cases when death occurred during the 1st day of life. In 23 infants coagulation studies were repeated on day 1,2 , 3 , and 10 .

None of these patients had hepatitis or other recognized liver disease.

For our study, these patients have been divided into two groups.

Group I. This group was comprised of 91 premature infants between 28 and 37 weeks of gestational age; 48 of these were considered as "thriving" and 43 as "sick" infants.

The 48 thriving infants were selected on the 1st day of life by the following criteria: no significant problems (i.e., no apparent infection, no severe RD). In this group we have included some infants with either

Table I. Clinical data for coagulation studies in 96 newborn infants ${ }^{1}$

\begin{tabular}{cc}
\hline \multicolumn{1}{c}{ Newborn infants } & $\begin{array}{c}\text { No. of } \\
\text { infants }\end{array}$ \\
\hline Less than 28 weeks & 5 \\
From 28-37 weeks (total) & 91 \\
Thriving (total) & 48 \\
Hypotrophic & 11 \\
Control group & 37 \\
Sick (total) & 43 \\
RD & 30 \\
HMD & 21 \\
Non-HMD & 9 \\
Heavy resuscitation for various reasons & 13 \\
\hline
\end{tabular}

$\overline{{ }^{1} \mathrm{RD} \text { : Respiratory distress; HMD : hyaline membrane disease. }}$ transient respiratory distress, minor amniotic aspiration, or grade $I$ hyaline membrane disease. None of the infants had acidosis or hypoxia. Thirty-seven infants were between $10 \%$ and $90 \%$ of the Lubchencho international units growth curve (IUGC) while 11 were below $10 \%$ for weight (hypotrophic).

The 43 sick premature infants presented with either RD (30 cases) or severe central nervous system depression requiring resuscitation (13 cases). In this group we excluded hypotrophic infants. Among the $30 \mathrm{RD}$ cases there were 21 with hyaline membrane grade II or III and 9 with congenital pneumonia or aspiration of amniotic fluid content.

Group II. This group included 5 infants younger than 28 gestational weeks without respiratory distress who were still in fair condition on the lst day of life.

\section{Technical Procedures}

Blood clotting factor assays. All assays were performed on capillary blood according to the method we have previously described [16]. The principle of this method is to dilute the capillary blood sample directly and to separate the diluted plasma in a second step by centrifugation.

Factors $V, I I$, and $V I I+X$ assays were performed according to Soulier and Larrieu [25], using as control the capillary blood from an adult donor, collected in the same way. For fibrinogen, we used the method described by Clauss [9] and developed by Vermylen et al. [28]. The fibrinogen titration curve was made using normal citrated plasma with a known fibrinogen level. It is necessary to apply a correction factor related to the difference between control and patient hematocrit levels.

Blood samples from newborn infants were collected in the following way. The foot was prewarmed in a sterile $40^{\circ}$ water bath and carefully dried after disinfection by alcohol. A sharp puncture was made on the heel with a long point lancet; $0.05 \mathrm{ml}$ capillary blood was immediately collected in a calibrated pipette and diluted with $0.95 \mathrm{ml}$ citrated buffer (1/20 blood dilution). To avoid early factor $V$ activation, the dilution procedure must be achieved less than $30 \mathrm{sec}$ after the puncture. This first sample is used for factors $V, I I$, and $V I I+X$ assays. Two subsequent samples were collected for fibrinogen assay ( $1 / 5$ blood dilution) and for microhematocrit.

Platelet counts. Platelet counts were performed on capillary blood but the results have not been included in this study because the tests were performed in 
another laboratory and on a blood sample not collected at the same time as that for clotting tests.

\section{Statistical Analysis}

Statistical significance of the observed results was computed by using the Student Fisher test for small samples.

\section{Results}

\section{Influence of Gestational Age on Blood Clotting Factor Levels}

The results obtained on the Ist day of life in the thriving infants were analyzed by gestational age (Table II). In the nonhypotrophic infants these results showed no significant difference (for the studied factors) between the various gestational age groups. In the hypotrophic infants, with gestational ages between 33 and 38 weeks, there was also no significant difference.

\section{Influence of Clinical Status on Blood Clotting Factor. Levels in Premature Infants}

Correlation between clinical status and blood clotting factor levels was studied only in the homogeneous group $I$ which included 37 nonhypotrophic premature infants in the same range of gestational age (28-37 weeks). There was no significant difference between the mean birth weight (thriving $1,910 \mathrm{~g}$, sD 394; sick $1,746 \mathrm{~g}, \mathrm{SD} 475 ; P>0.50$ ) and gestational age (thriving 32.8 weeks, sD 2.6 weeks; sick 32 weeks, sD $2.8 ; P>$ $0.50)$.

\section{Biological Findings}

Factor $V$ (Figs. 1 and 2). In all 80 infants of group $I$, factor $V$ levels progressively increased during the first days of life, reaching the adult mean level by the 10 th
FACTOR V ( PROACCELERIN )

IN NEWBORN FROM 28 TO 37 WEEKS

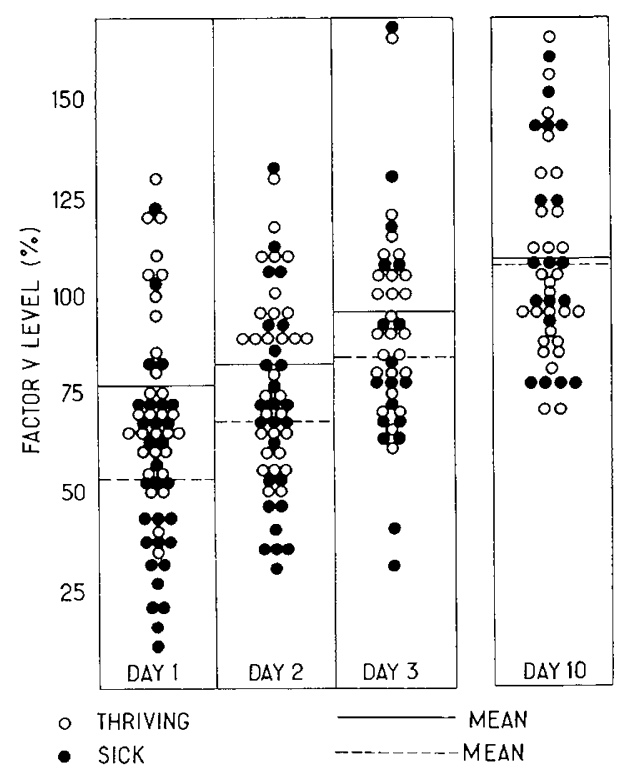

Fig. l. Factor $V$ level in premature infants. Individual results and their evolution during the first days of life.

day. This finding was observed in both the thriving infants and the sick infants who survived, in spite of the fact the latter started at a significantly lower level.

On day 1 , the mean factor $V$ level in the thriving group was $78 \%$ (sD 25\%). In the sick group, the mean factor $V$ level was significantly lower: $54 \%$ (sD 26\%), with $P<0.001$.

When the sick infants were separated into two groups, one with respiratory distress syndrome (RDS) and the other without, there was a highly significant difference between factor $V$ levels among those infants with RDS (49\% sD 26\%) with $P<0.001$ and thriving infants, whereas there was no significant difference be-

Table II. Levels of coagulation factors in thriving premature infants according to gestational age

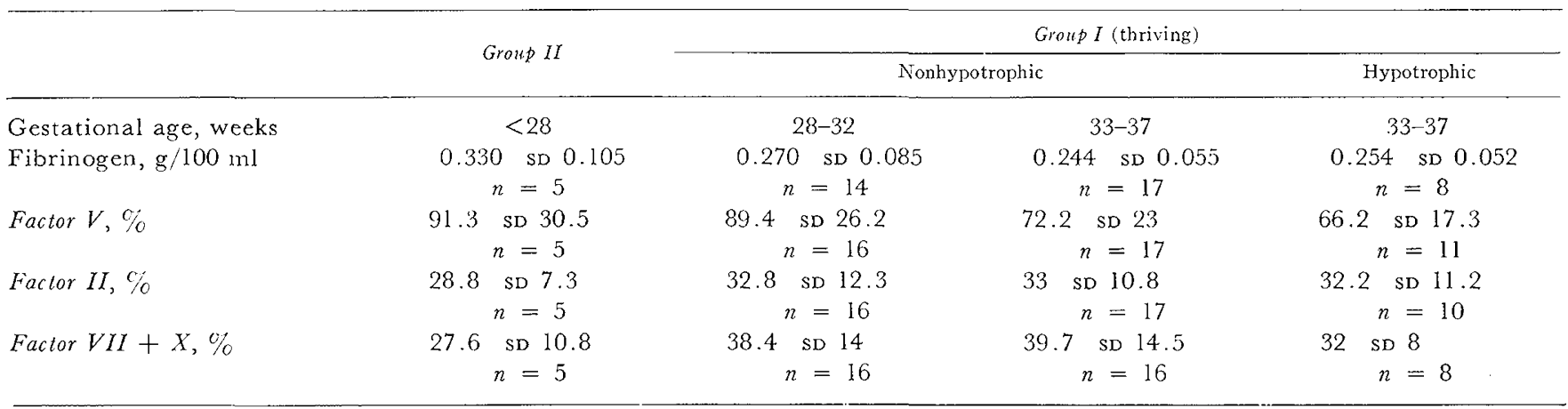




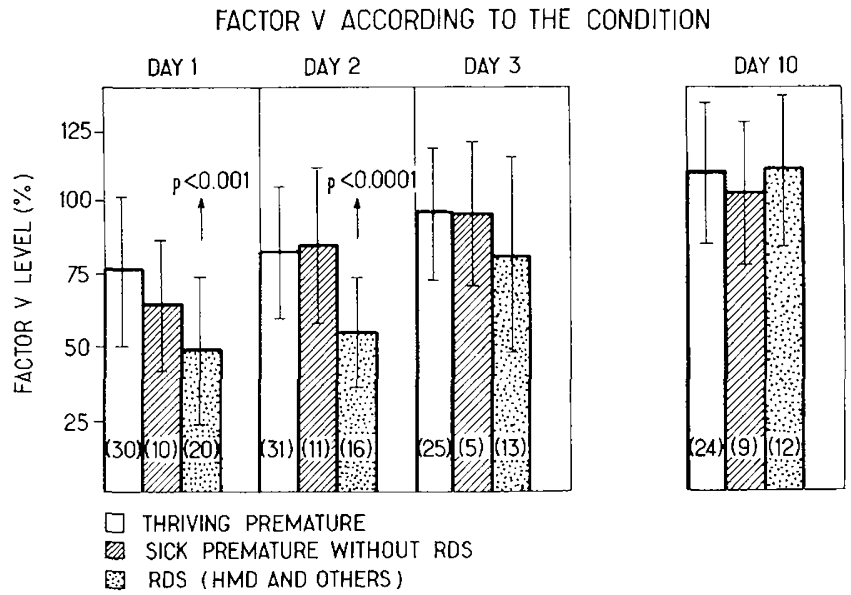

Fig. 2. Factor $V$ level in thriving and sick premature infants during the first days of life (The top of each column indicates the mean level observed in the studied groups \pm I sD; between brackets the number of studied cases in the group). RDS: Res. piratory distress syndrome; $H M D$ : hyaline membrane disease.

\section{FACTOR ॥ ACCORDING TO THE CONDITION}
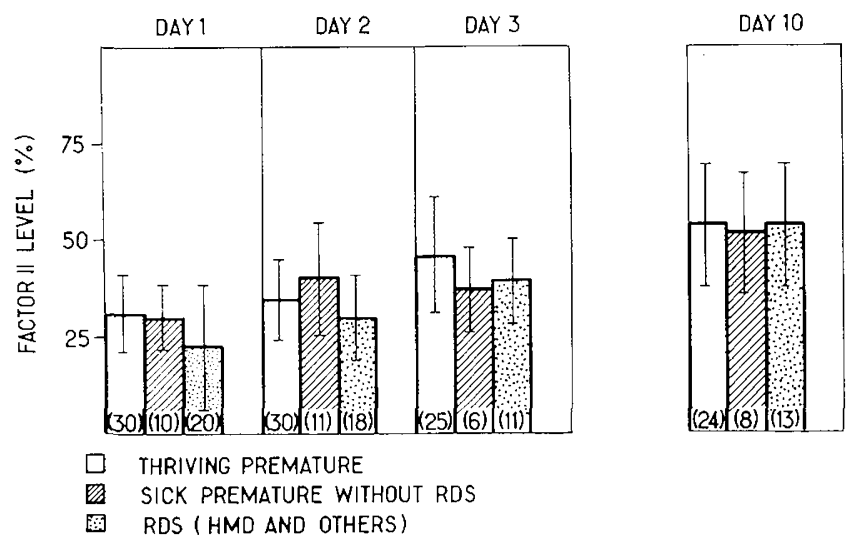

Fig. 3. Prothrombin level in thriving and sick premature infants during the first days of life. (The top of each column indicates the mean Ievel observed in the studied groups $\pm 1 \mathrm{~s}$ ); betreen brackets the number of studied cases in the group.) RDS: Respiratory distress syndrome; $H M D$ : hyaline membrane disease.

tween the levels of those without RDS (64\% sD 23\%) and the thriving infants. Within the sick group there was no statistical difference between the factor $V$ levels in those infants with RDS and those without.

Factor II (Fig. 3). All of the infants in this study received vitamin $\mathrm{K}_{1}$ at birth $(\mathrm{I}-2 \mathrm{mg} / \mathrm{kg})$. As with factor $V$, factor II levels increased progressively during the first 10 days of life, but did not reach the adult level by the 10 th day in any group. The mean factor II level at day 10 was $53 \%$ sD $16 \%$ for both the sick and the thriving group.
On the 1st day of life, no significant difference was observed between the mean value in the thriving group $(32 \%, \mathrm{SD} 10 \%)$ and that of infants with RDS $(23 \%$, so $16 \%)$ nor that of sick infants without RDS $(30 \%$ sD $8 \%)$. We did not find any statistical correlation between factor $V$ and $I I$ levels in the thriving group. However, in the group of sick infants, factor II level at day 1 was statistically related to factor $V$ level $(P=$ 0.01 for $r=0.7290$ ).

Factor VII $+X$. These results were very similar to those of factor II. On day 10, the mean level or factor. $V I I+X$ was approximately $60 \%$ in all the infants studied. Mean values on the 1 st day of life were $41 \%$ SD $12 \%$ in the thriving group, $26 \%$ SD $12 \%$ in the infants with RDS, $31 \%$ SD $13 \%$ in the sick group without RDS. This assay was performed in only half of each group, and the $P$ values were not calculated, in view of the small number of cases.

Fibrinogen (Fig. 4). The fibrinogen level varied greatly from infant to infant irrespective of their clinical condition. On day 10 the mean value was $280 \mathrm{mg} /$ $100 \mathrm{ml}$, sD $80 \mathrm{mg} / 100 \mathrm{ml}$ in the thriving infants and 250 $\mathrm{mg} / 100 \mathrm{ml} \mathrm{so} 70 \mathrm{mg} / 100 \mathrm{ml}$ in the sick infants.

On day $l$ the mean fibrinogen level in the thriving group was $250 \mathrm{mg} / 100 \mathrm{ml}$, sD $80 \mathrm{mg} / 100 \mathrm{ml}$ while in the sick group it was significantly lower: $200 \mathrm{mg} / 100$ $\mathrm{ml}$ sD $100 \mathrm{mg} / 100 \mathrm{ml}$ with $P<0.02$. When the sick infants were separated into two groups one with RD and the other without, there was a significant difference between the thriving group and those with RDS $190 \mathrm{mg} / 100 \mathrm{sD} 10 \mathrm{mg} / 100 \mathrm{ml}$ with $P<0.02$ while

\section{FIBRINOGEN ACCORDING TO THE CONDITION}
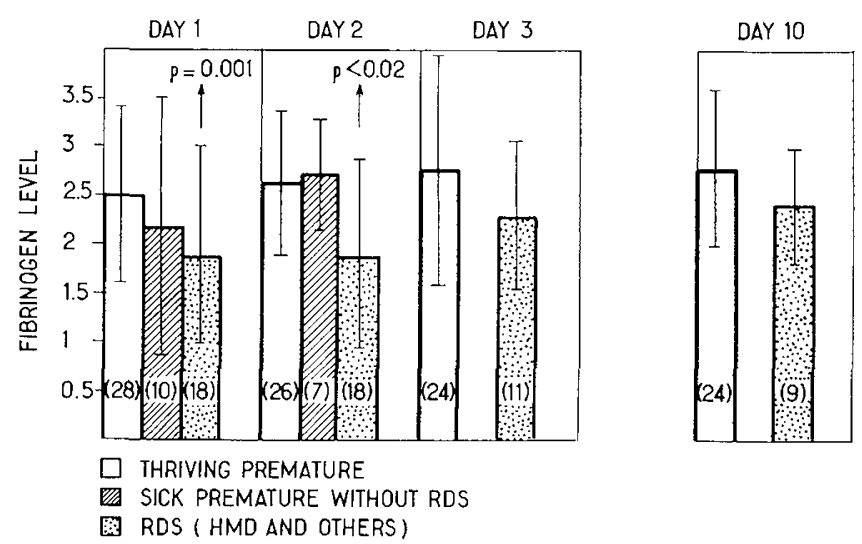

Fig. 4. Fibrinogen level in thriving and sick premature infants during the first days of life. (The top of each column indicates the mean level observed in the studied groups $\pm 1 \mathrm{sp}$; between brackets the number of studied cases in the group.) RDS: Respiratory disease syndrome; HMD: hyaline membrane disease. 


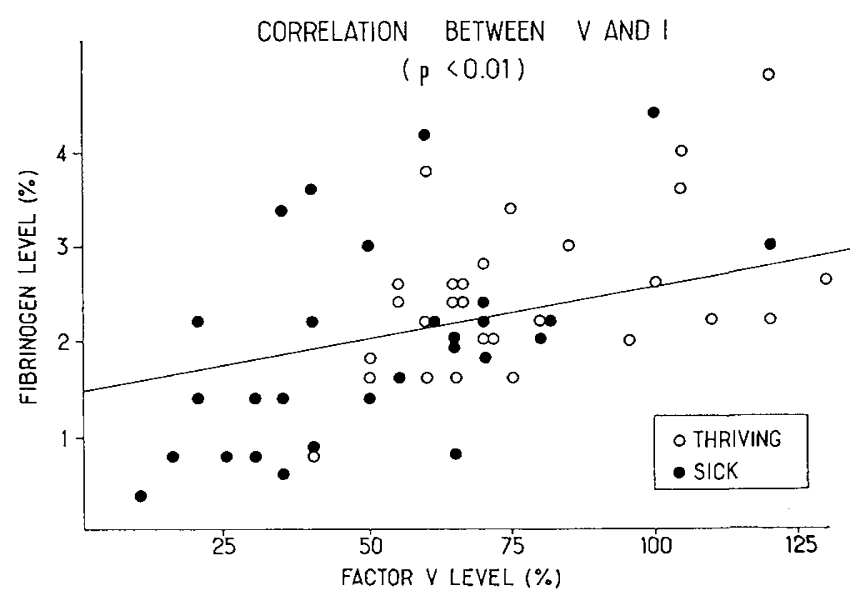

Fig. 5. Correlation between fibrinogen and factor $V$ levels at the lst day of life in the premature infants.

there was no significant difference between the thriving group and those without RDS $220 \mathrm{mg} / 100 \mathrm{ml} \mathrm{sD}$ $130 \mathrm{mg} / 100 \mathrm{ml}$. As was the case for factor $V$, within the sick group there was no statistical difference between fibrinogen levels in those infants with RDS and those without. On the lst day of life a statistical correlation was found between fibrinogen and factor $V$ levels in the thriving group as well as in the group of sick infants $(P<0.01$ for $r=0.5570$ (Fig. 5$))$.

\section{Clinical Correlation}

Thriving group. All 37 infants survived except one who died secondarily of a late peritonitis. There were no clinical hemorrhagic manifestations in any of these infants. From day $I$ to day 10 , factor $V$ levels were always above $50 \%$ exception two cases $(35 \%$ and $42 \%$, respectively) and the fibrinogen levels were consistently higher than $160 \mathrm{mg} / 100 \mathrm{ml}$.

Sick group. Among these 43 infants, at day 10, there were 25 survivors, 4 of them with hemorrhagic manifestations. Among the 18 infants who died before the 10 th day, 15 were studied by postmortem examination, which revealed 11 cases with hemorrhagic manifestations, 2 of which had typical pathologic features of disseminated intravascular coagulation. Blood clotting factor levels were significantly lower in the infants with hemorrhagic manifestations than in others of the same group (Table III) with $P<0.01$ for factor $V$ and $P<0.01$ for fibrinogen.

\section{Discussion}

To the best of our knowledge this is one of the first extensive reports on the use of micromethods for deter- mining capillary blood clotting factor levels in premature infants during the newborn period. Literature analysis as recently given by Bleyer and coworkers [4] is fraught with many difficulties. (1) Most publications deal with only a few cases and therefore are of questionable statistical value. (2) For practical reasons, premature infants and full term neonates are seldom studied by the same team using the same technical procedures. (3) One cannot compare values of vitamin K-dependent factors between those infants receiving vitamin $\mathrm{K}$ at birth with those not systematically receiving vitamin $\mathrm{K}$. (4) The method of blood collection is of critical importance at this age and can strongly influence the observed levels of factor $V$ and VIII as has been demonstrated [16].

In spite of these limitations, the results obtained in this study for thriving premature infants were quite comparable with those reported in the literature for normal term infants and for normal premature infants $[6,12,14,18,22-24,27]$ macro collecting techniques. Vitamin K-dependent factors (II, IX, and VII $+\mathrm{X}$ ) are low despite vitamin $\mathrm{K}$ administration but do not decrease at day 2 or 3 [29]. Fibrinogen levels have been reported in the normal range and factor $V$ levels are usually slightly below the normal adult range, especially in premature infants $[1,8,13,19,23]$. In this study, we found factor $I I, V I I$, and $X$ levels to be about $30-40 \%$ on day 1 , increasing slowly to $40-70 \%$ by day 10. Fibrinogen levels were in the normal range $(250 \mathrm{mg} / 100 \mathrm{ml})$ whereas factor $V$ levels were initially slightly low (78\%) increasing to nearly $100 \%$ by the 3rd day of life. In this study, there was no apparent relation between blood clotting factor levels and gestational age.

The results obtained in this study of sick infants compare favorably with those reported in the literature, which contains many individual case reports of abnormalities of blood clotting factor levels in sick infants $(10,12,24)$. In extensive studies reported by Hathaway et al. [15], Markarian et al. [20, 21], and

Table III. Correlation between hemorrhagic tendency, prognosis, and blood clotting factors levels in sick premature infants on day 1

\begin{tabular}{|c|c|c|c|c|}
\hline Sick infants & $\begin{array}{l}\text { No. of } \\
\text { cases }\end{array}$ & $\begin{array}{l}\text { Mean Factor V } \\
\text { level, } \%\end{array}$ & $\begin{array}{l}\text { Mean fbrinogen } \\
\text { level, } \mathrm{g} / 100 \mathrm{ml}\end{array}$ & $\begin{array}{c}\text { Died, } \\
\text { no. }\end{array}$ \\
\hline $\begin{array}{l}\text { No hemorrhagic } \\
\text { tendency }\end{array}$ & 28 & $\begin{array}{c}68 \\
\mathrm{SD} \pm 24\end{array}$ & $\begin{aligned} & 0.2 \\
\mathrm{SD} & \pm 0.09\end{aligned}$ & 7 \\
\hline $\begin{array}{l}\text { Hemorrhagic tend- } \\
\text { ency } \\
P \text { value }\end{array}$ & 15 & $\begin{array}{c}32 \\
\mathrm{SD} \pm 16 \\
<0.001\end{array}$ & $\begin{array}{c}0.13 \\
\mathrm{SD} \pm 0.10 \\
<0.001\end{array}$ & 11 \\
\hline
\end{tabular}


Alstadtt [3], the hypothesis of the frequent occurrence of DIC in sick premature infants is presented. In our study, low levels of blood clotting factors were most frequently observed in premature infants considered sick on clinical grounds, most of them having respiratory distress (due to hyaline membrane (lisease). In this group there were significantly low levels of factor $V$ and fibrinogen with a good correlation between these two factors. For vitamin K-dependent factors (II, VII, and $\mathrm{X}$ ) the mean level in the sick group was also lower than in the thriving group, but because of large individual variations, the significance of this finding is questionable.

What is the significance of these abnormalities in sick premature infants?

As described in adults, older infants, and neonates [2], DIC is characterized by the usual association of thrombocytopenia with low levels of factor $V$ and fibrinogen plus elevated fibrin-split products. The frequent occurence of the so-called "in vitro hypercoagulability" $[17,18,20,21]$ at birth as well as the occasional detection of fibrin-split products in normal neonates $[5,11,26]$ suggest the occurence of DIC in sick premature infants might be an accentuation of an almost physiologic state. It has also been demonstrated [13] in animals that anoxia and acidosis, which are frequent components of most pathologic conditions in premature infants, favor the occurence of DIC. This might explain the lack of correlation between biologic findings and very specific clinical syndromes.

The correlation between biologic data and clinical pathology is somewhat more difficult to establish for the following reasons. (1) Local hemorrhages may occur without any detectable abnormality of the systemic hemostatic system. (2) The absence of bleeding does not exclude the possibility of grossly abnormal levels of blood clotting factors. (3) Pathologic data obtained at autopsy are difficult to evaluate because in most cases of suspected DIC only optical data are available and these techniques can demonstrate only severe thrombotic lesions [7]. Minor capillary obliterations by platelet plugs and fibrin threads can be seen only under the electron microscope or with immunofluorescent techniques.

Nevertheless, in this study, a statistical correlation between bleeding tendencies and abnormal coagulation studies became evident when we included apparently minor symptoms such as bleeding from venipuncture sites, nares, hematomas of drug injection sites, presence of blood in the tracheal and gastric fluid obtained at suction, slight hematuria, etc. In our study of sick premature infants, the occurrence of hemostatic defects seemed to bear a bad prognosis, the mortality being significantly higher in this group than in sick premature infants without detectable hematologic defects.

With our present limited understanding of the many factors possibly involved in the production of abnormal hematologic findings, one cannot say whether the hemostatic abnormalities present in severely ill infants are the result of the illness or whether they participate actively in a disease process which is expressed finally as DIC. Furthermore, we do not know for certain whether what is known about the coagulation system in adults can be applied to the coagulation system of newborn infants.

It is hoped that the use of micromethods for determining capillary levels of the various blood coagulation factors will facilitate the collection of data needed to further elucidate the many unexplained factors involved in the complicated process leading to DIC.

\section{Summary}

The results of capillary levels of blood coagulation factors (fibrinogen, factor $V$, factor $I I$, and factor VII $+X)$ in 96 premature infants have been analyzed in relation to gestational age and clinical condition.

There was no apparent relation between gestational age and blood clotting factor levels. The premature infant considered as sick on clinical ground had a lower level of fibrinogen and factor $V$ than those considered as thriving, and there was a good correlation between the level of these two factors. This was only true for the sick infants with RDS.

A lower level of these two factors was also found in the group of sick infants who had hemorrhagic tendencies, compared with those infants without signs of hemorrhage. Among these infants with RDS, there was no difference between those infants with hyaline membrane disease and those whose distress was due other causes.

\section{References and Notes}

1. Aballt, A. J., and Deramerens, S.: Coagulation changes in the neonatal period and in early infancy. Pediat. Clin. N. Amer., 9: 785 (1962).

2. Amildgard, C. F.: Recognition and treatment of intravascular coagulation. J. Pediat., 74: 163 (1969).

3. Alstadtr, L., Dennis, L., Sondell, H., Malan, A., Harrisson, V., Hedvall, G., Eichielberger, J., Fogel, B., and Stahlman, 
M.: Disseminated intravascular coagulation and hyaline membrane diseasc. Biol. Neonatorum, 19:227 (1971).

4. Bleyer, A., Hakami, N., and Shepard, H.: The development of hemostasis in the human fetus and newborn infant. $J$. Pediat., 79: 838 (1971).

5. Bonifaci, E., Bagigio, P., and Gravina, E.: Demonstration of split products of fibrinogen in blood of normal newborn. Biol. N'conatorum, J2: 29 (1968).

6. Bonnar, J., McNicol, G. P., and Dougins, A. S.: The blood coagulation and fibrinolytic systems in the newborn and the mother at birth. J. Obstet. Gynaec. Brit. Commonw., 78: 355 (1971).

7. Boyp, J. F.: Disseminated fibrin thrombocmbolism among neonates dying within 48 hours of birth. Arch. Dis. Childhood, f2: 40I (1967).

8. Breton, A., Goudrmanis, M., Hutin, A., Caudrelier, J. R., ANd Gaudifr, B.: Etude de la coagulabilité sanguine chez le nouveau-né prématuré. Arch. Fr. Pediat., 17: 143 (1960).

9. CitAus, A.: Gerinnungs physiologische schnell methode zur bestimmung des fibrinogenes. Acta Haematol., 17: 237 (1957).

10. Chessfi., J. M., AND Wrgeifsworth, J. S.: Coagulation studies in severe birth asphyxia. Arch. Dis. Childhood, f6: 253 (1971).

I1. Chresser, J. M.: The significance of fibrin degradation products in the blood of normal infants. Biol. Neonatorum, 17: 219 (1971).

12. Desibuquots, (;., Lffroux, M. E., Laugier, J., Rollani), J. C., Rossignol, O., Brfanond, J. L., And Lrroy, J.: Problemes de diagnostic et de traitement des syndromes de défibrination chez le nouveau-né. Arch. fr. Pediat., 27: 797 (1970).

13. HARDAWAY, R. M.: Shock and disseminated intravascular coagulation. In: Diffuse intravascular clotting. Thromb. Diath. Hacmorrh. (Suppl. 20), 121 (1966).

14. Hathaway, W. E.: Coagulation problem in the newborn infant. Pediat. Clin. N. Amer., 17: 929 (1970).

15. Hathaway, W. E., Mula, M. M., and Pechet, G. S.: Disseminated intravascular coagulation in the newborn. Pediatrics, t3: 233 (1969).

16. Herlet, A., AND Josso, F.: Etude analytique de la coagulation sur microprélèvements de sang capillarie. Pathol. Biol., 20: $165,(1972)$.

17. Kocir, F. R.: Bluteweissuntersuchungen bei Neugeboren unter Berücksichtigung der Gerinnungsstorungen. \%. Geburtsh. Beilageheft., 159 (1962).

18. Lakrifu, M. J., Soulifk, J. P., AnI) Minkowski, A.: Le sang du cordon ombilical: Etude complète de la coagulabilité: Comparaison avec le sang materncl. Et. Neonatales, 1: 39 (1952).

19. Lato, M., Srveri, P., and Antonfldi, G.: Les facteurs de coagulation chè le prématuré. lattante, 30:57 (1959).

20. Markarian, M., Githiens, J. H., Roseniblut, E., Firnandez, F., JACkson, J. J., BANNon, A. E., l.indtey, A., Lubchenco, L. (), AND Mar'orefi.r, R.: Hypercoagulability in premature infants with special reference to the respiratory distress syndrome and hemorrhage. I. Coagulation studies. Biol. Neonatorum, 17: 84 (1971).

21. Markarian, M., Lubchinco, I. O., Rosenblut, E., Fernandez, F., LANG, D., JАCKSON, J. J., BANNON, A. E., LindLEy, A., Githens, J. H., ANI MAR'Torfi., R.: Hypercoagulability in premature infants with special referecne to the respiratory distress syndrome and hemorrhage. II. The effect of heparin. Biol. Neonatorum, 17:98 (1971).

22. Nossei, H. I., I.anzkowsky, P., Ifevy, S., Mibashan, R. S., and Hansin, J. I). L.: A study of coagulation factor levels in rromen during labor and in their newborn infants. Thromb. Diath. Haemorrh., 16: 185 (1966).

23. Rogner, G.: Die blutgerinnung bei Frühgeburten. Z. Kinderkheilk., $84: 197$ (1960).

24. Sainim-Martin, J., Huault, G., Josso, F., Jori.y, J. B., KaCIANFr, J., AND FFron, J. P.: Coagulopathies de consommation chez le nouveau-né: A propos de 8 observations. Arch. Fr. Pediat., 28: 17 (1971).

25. Soutifr, J. P., and IARrifu, M. J.: Etude analytique des temps de Quick allongés. Dosage de la prothrombine, de la proconvertine et de la proaccélérine. Sang, 23: 459 (1952).

26. Stifhi, E., and (tamanof, 1). U.: Split product of fibrin in serum of newborns. Pedlattics, 43 : 770 (1969).

27. Suchon, N., Thouverliz, J. P., and Bfillevill.F, J.: Microméthodes applicables a l'étude de la coagulation chez le nouveau-né. Coagulation, $l: 361$ (1968).

28. Vermyien, G., de Vrecker, K. A., nNo Verstraete, M.: $\Lambda$ simple method for the instantaneous quantitation of fibrinogen: 'The FPT-test. Clin. Chim. Acta, $8: 418$ (1963).

29. Wefrinci, K. W.: Hémorragie du nouveau-né et prophylaxic par la vitamine K. J. Pediat., 61: 686 (1962).

30. Requests for reprints should be addressed to: Anne. HurietBrRK JFnsen, M.I., Department of Hematology, Centre Hospitalicr Universitaire, I'ecker-Enfants Malades, 156 rue dè Vaurgirard, 75015 Paris, France.

31. Accepted for publication March 5, 1973. 